\title{
EFFECTS OF PROCESS VARIABLES ON THE STRUCTURE AND PROPERTIES OF HOT ROLLED 718 BAR
}

\author{
J. M. Moyer, L. A. Jackman, R. S. Minisandram, and T. W. Miles \\ Allvac, an Allegheny Technologies Company \\ 2020 Ashcraft Avenue \\ Monroe, North Carolina 28110
}

\begin{abstract}
An experiment was statistically designed to determine the effects of ten variables on the microstructure and mechanical properties of alloy 718 bar produced on Allvac's state-of-the-art, continuous, 16-stand rolling mill. A series of 32 rolling trials was conducted in which each variable was set at one of two levels. Microstructures and mechanical properties were determined on samples taken after the material exited selected stands. Surface temperatures of the moving metal were measured with pyrometers at six locations along the rolling mill.

The grain size and mechanical properties after stand 4 are determined largely by the initial billet temperature. As rolling progresses, the speed of the finishing portion of the mill becomes increasingly important until it finally becomes the dominant factor. Correlations exist between surface temperature, microstructure, and mechanical properties; these include the influence of delta phase distribution on stress-rupture properties.

Experimental results agree well with predictions of both surface and internal temperatures made with a steady state, finite element model. The model is now available for optimizing rolling procedures.
\end{abstract}




\section{Introduction}

In late 1991. Allvac commissioned a state-of-the-art, continuous rolling mill for producing straight and coiled bar and rod products in the size range of 13 to $102 \mathrm{~mm}(0.5$ to $4 \mathrm{in})$ in diameter. Many of the superalloy products produced on this mill need special rolling procedures designed to achieve specific structure and property requirements. In an effort to help optimize rolling procedures for alloy 718 . a statistically designed experiment involving 32 rolling trials to evaluate ten variables was conducted. Data from this experiment were also used to help verify a computer model that had been developed to optimize rolling procedures. Because of the large amount of data generated, only highlights of the work are reported here.

\section{The Rolling Mill}

The 16-stand rolling mill includes a 4-stand roughing mill, an 8-stand intermediate mill. and a 4-stand finishing mill. A unique free space with a conveyor is located between the roughing and intermediate mills so that the rougher speed can be set independently from the intermediate/finish mill speed. This mill is described in detail elsewhere $(1,2)$ and is illustrated in Figure 1.

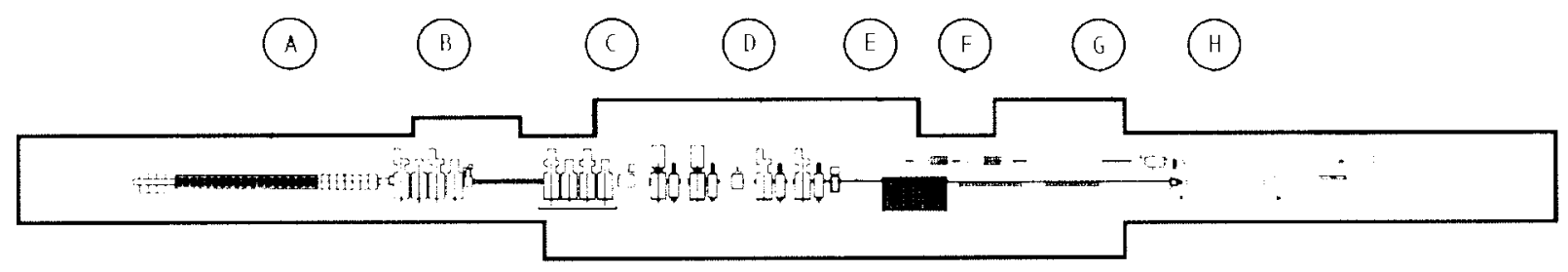

Figure 1: Richburg rolling mill is comprised of: (A) Induction furnace, (B) Roughing mill. (C) Intermediate mill, (D) Finish mill. (E) Cooling bed, (F) Rod mill section. (G) Laying head and cooling conveyor, and $(H)$ Coiler. Reference 2.

\section{The Finite Element Model}

In order to assist in process design and optimization, a steady state finite element model (3) of the multi-stand mill is now available for use. In this model each of the 16 stands is analyzed separately as a steady state process, with thermal and mechanical information being passed to adjacent stands iteratively until a compatible solution is reached. The material is assumed to flow as an incompressible, non-Newtonian fluid with a viscosity that is specified as a function of temperature, effective strain-rate and accumulated effective strain. For each stand. the momentum and energy equations are solved in a coupled fashion to give material deformation and temperature information. A unique algorithm is used to determine the contact region between the workpiece and the rolls. The cooling of the bar that takes place between stands is efficiently modeled by analyzing the cooling of a single cross-section as it travels from the exit of one stand to the entrance of the next stand. Interstand tensions are estimated by representing the connections between the control volumes in two adjacent stands by a single viscous element. 


\section{Procedure}

A total of 32 billets at $98.4 \mathrm{~mm}$ (3.875 in) diameter were rolled to $13.5 \mathrm{~mm}(0.531 \mathrm{in})$ diameter, each billet being rolled using a unique combination of parameters as determined by a statistically designed fractional (1/32) factorial experiment. Ten variables were investigated at two levels each. Three are unique to the Allvac mill and were found not to affect the product significantly. The other seven are listed in Table I.

\section{Table I. Variables Investigated in the Designed Experiment}

\begin{tabular}{|c|c|c|}
\hline Variable & Low Setting & High Setting \\
\hline Billet starting temperature & $996^{\circ} \mathrm{C}\left(1825^{\circ} \mathrm{F}\right)$ & $1107^{\circ} \mathrm{C}\left(2025^{\circ} \mathrm{F}\right)$ \\
\hline Initial billet grain size & ASTM 6 & ASTM 8 \\
\hline $\begin{array}{l}\text { Soak time in box furnace after induction } \\
\text { heating (furnace not shown in Figure } 1 \text { ) }\end{array}$ & 5 minutes & 15 minutes \\
\hline Roughing mill speed (exiting stand 4) & $34 \mathrm{~m} / \mathrm{min}(110 \mathrm{ft} / \mathrm{min})$ & $42 \mathrm{~m} / \mathrm{min}(138 \mathrm{ft} / \mathrm{min})$ \\
\hline $\begin{array}{l}\text { Intermediate/Finish mill speed (exiting stand } \\
\text { 16) }\end{array}$ & $\begin{array}{l}213 \mathrm{~m} / \mathrm{min} \\
(700 \mathrm{ft} / \mathrm{min})\end{array}$ & $\begin{array}{l}305 \mathrm{~m} / \mathrm{min} \\
(1000 \mathrm{ft} / \mathrm{min})\end{array}$ \\
\hline Delay time after the roughing mill & Short & Long \\
\hline Cooling after finish rolling at stand 16 & $\mathrm{Air} \mathrm{Cool}$ & Water Quench \\
\hline
\end{tabular}

Surface temperatures of the moving metal were measured automatically with pyrometers installed at six locations along the rolling mill. Mechanical properties and microstructure, including grain size, were evaluated using samples cut "on the fly" after stands 4 (at the end of the rougher), 8 (midway through the intermediate mill), and 12 (at the end of the intermediate mill) as well as on final product after stand 16. Mechanical properties tested include room temperature tensile, $649^{\circ} \mathrm{C}\left(1200^{\circ} \mathrm{F}\right)$ tensile, and stress-rupture at $649^{\circ} \mathrm{C}\left(1200^{\circ} \mathrm{F}\right) / 758 \mathrm{MPa}$ $(110 \mathrm{Ksi})$. All three mechanical tests were run on samples taken after stands 4 and 16 . Only stress-rupture tests were run on samples cut after stands 8 and 12 . Prior to testing, all mechanical test samples were heat treated as follows:

$$
\begin{aligned}
& 954^{\circ} \mathrm{C}\left(1750^{\circ} \mathrm{F}\right)-1 \mathrm{hr}-\text { Air Cool } \\
& 718^{\circ} \mathrm{C}\left(1325^{\circ} \mathrm{F}\right)-8 \mathrm{hrs}-\text { Furnace Cool at } 56^{\circ} \mathrm{C} / \mathrm{hr}\left(100^{\circ} \mathrm{F} / \mathrm{hr}\right) \text { to } \\
& 621^{\circ} \mathrm{C}\left(1150^{\circ} \mathrm{F}\right)-8 \mathrm{hrs}-\text { Air Cool. }
\end{aligned}
$$

Duplicate tests were not run due to the large number of mechanical samples required. Multiple regression analyses were performed on the data to isolate the significant individual variables and interactions.

Because of the interesting results obtained for the stress-rupture properties, additional micros were prepared by polishing and etching selected, broken test bars. The grain sizes of these micros were determined to the nearest 0.1 ASTM number using the Heyn intercept technique in ASTM E 112 (4). The total length of delta phase needles in each of 22 broken test bars was determined manually by adding up the individual lengths and taking the average of four SEM microphotos at $1000 \mathrm{X}$. Correlations between stress-rupture properties, grain size, and total delta length were investigated. The initial results of that study are reported here.

Results comparing the predictions of the finite element model with experimental results in the rougher (stands 1-4) for alloy 718 are presented in this paper. Deformation and temperature data were recorded as follows. The billet shape at the exit of each stand was obtained by shutting down the mill during the rolling process with the billet in stands 2,3 and 4 simultaneously. Sample cross sections were cut from the billet between successive stands to 
give the exit dimensions. Billet surface temperatures were measured using hand-held infrared pyrometers at five locations. Other pertinent data such as stand settings and steady state roll speeds also were recorded.

\section{Results}

\section{Tensile Tests}

A summary of the tensile test results for samples cut immediately after stand 4 appears as Table II. Because of space constraints, only the average and range of data are presented, first for the lower setting for the most significant variable and then for the higher setting. When the most significant variable is given as "Interaction", a combination of two variables has the greatest effect. Variables in brackets are not significant at the $90 \%$ confidence limit. Table II shows that the most significant individual variable is the temperature of the box furnace that heated the billet immediately prior to rolling. In several cases an interaction between two variables was found to be more significant than the furnace temperature, but even one of those interactions includes the furnace temperature.

Table II. Stand 4 Tensile Test Results

\begin{tabular}{|c|c|c|c|c|c|c|}
\hline \multirow{2}{*}{$\begin{array}{c}\text { Test } \\
\text { Temp. }\end{array}$} & Property & Most & \multicolumn{2}{|c|}{ Low Setting } & \multicolumn{2}{c|}{ High Setting } \\
\cline { 4 - 7 } & & $\begin{array}{c}\text { Significant } \\
\text { Variable }\end{array}$ & Avg. & Range & Avg. & Range \\
\cline { 4 - 7 } & & & & & \\
\hline \multirow{2}{*}{$\begin{array}{l}\text { Room } \\
\text { Temp. }\end{array}$} & Ultimate Strength (Ksi) & Fce. Temp. & 204.7 & $200.4-209.1$ & 195.4 & $191.4-199.9$ \\
\cline { 2 - 7 } & Yield Strength (Ksi) & Interaction & 172.1 & $166.9-176.2$ & 169.9 & $165.5-175.0$ \\
\cline { 2 - 7 } & Elongation (\%) & (Interaction) & 22.1 & $19-24$ & 23.0 & $20-25$ \\
\cline { 2 - 7 } & Reduction of Area (\%) & (Fce. Temp.) & 46.8 & $43.8-50.9$ & 49.5 & $45.7-53.2$ \\
\hline $1200^{\circ} \mathrm{F}$ & Ultimate Strength (Ksi) & Fce. Temp. & 169.0 & $164.2-176.8$ & 155.8 & $149.0-162.1$ \\
\cline { 2 - 7 } & Yield Strength (Ksi) & Fce. Temp. & 143.2 & $139.0-146.1$ & 137.3 & $131.3-142.3$ \\
\cline { 2 - 7 } & Elongation (\%) & (Interaction) & 23.2 & $21-26$ & 24.2 & $22-27$ \\
\cline { 2 - 7 } & Reduction of Area (\%) & (Interaction*) & 49.3 & $37.3-57.0$ & 51.9 & $46.9-56.7$ \\
\hline
\end{tabular}

* Interaction includes the furnace temperature.

( ) Variable not significant at the $90 \%$ confidence level.

The minimum requirements for a typical specification, AMS 5662 (5), are listed in Table III. All the strength and ductility results at stand 4 meet these requirements, regardless of the procedure used to roll the material.

Table III. Requirements of Specification AMS 5662

\begin{tabular}{|l|l|l|c|}
\hline \multicolumn{1}{|c|}{ Test } & \multicolumn{1}{|c|}{ Conditions } & \multicolumn{1}{c|}{ Property } & Requirement \\
\hline \multirow{5}{*}{ Tensile } & Room Temperature & Ultimate Strength & $185 \mathrm{Ksi}$ \\
\cline { 3 - 4 } & & Yield Strength & $150 \mathrm{Ksi}$ \\
\cline { 3 - 4 } & & Elongation & $12 \%$ \\
\cline { 2 - 4 } & Reduction of Area & $15 \%$ \\
\cline { 2 - 4 } & \multirow{2}{*}{$1200^{\circ} \mathrm{F}$} & Ultimate Strength & $145 \mathrm{Ksi}$ \\
\cline { 3 - 4 } & & Yield Strength & $125 \mathrm{Ksi}$ \\
\cline { 3 - 4 } & & Elongation & $12 \%$ \\
\cline { 3 - 4 } & & Reduction of Area & $23 \mathrm{hrs}$ \\
\hline \multirow{3}{*}{ Stress-Rupture } & $1200^{\circ} \mathrm{F} / 110 \mathrm{Ksi}$ & Life & $4 \%$ \\
\cline { 3 - 4 } & & Elongation & $15 \%$ \\
\hline
\end{tabular}


In Table IV are the tensile test results for samples cut after stand 16 . These values also meet the requirements of the specification. Although sometimes the most significant variable is an interaction, the most important individual variable this time appears to be the speed of the finish portion of the rolling mill. One of the interactions includes the finish speed (**) but none include the cooling rate of the bar after stand 16 .

Table IV. Stand 16 Tensile Test Results

\begin{tabular}{|c|c|c|c|c|c|c|}
\hline \multirow{2}{*}{$\begin{array}{c}\text { Test } \\
\text { Temp. }\end{array}$} & \multirow[t]{2}{*}{ Property } & \multirow{2}{*}{$\begin{array}{c}\text { Most } \\
\text { Significant } \\
\text { Variable }\end{array}$} & \multicolumn{2}{|c|}{ Low Setting } & \multicolumn{2}{|c|}{ High Setting } \\
\hline & & & Avg. & Range & Avg. & Range \\
\hline \multirow{4}{*}{$\begin{array}{l}\text { Room } \\
\text { Temp. }\end{array}$} & Ultimate Strength (Ksi) & Finish Speed & 207.1 & $204.4-209.2$ & 200.5 & $197.3-203.9$ \\
\hline & Yield Strength (Ksi) & Interaction $* *$ & 178.1 & $175.2-181.3$ & 175.7 & $172.6-179.8$ \\
\hline & Elongation $(\%)$ & Interaction & 22.5 & $21-24$ & 23.5 & $20-26$ \\
\hline & Reduction of Area ( $\%$ ) & Fce. Temp. & 46.0 & $43.4-50.9$ & 48.3 & $44.6-52.9$ \\
\hline \multirow[t]{4}{*}{$1200^{\circ} \mathrm{F}$} & Ultimate Strength (Ksi) & Finish Speed & 170.6 & $164.5-173.8$ & 164.6 & $159.2-169.1$ \\
\hline & Yield Strength (Ksi) & (Interaction) & 147.3 & $144.7-150.2$ & 145.6 & $140.0-149.1$ \\
\hline & Elongation $(\%)$ & (Cooling Rate) & 22.4 & $19-27$ & 24.1 & $18-30$ \\
\hline & Reduction of Area (\%) & Cooling Rate & 51.2 & $37.5-61.8$ & 44.7 & $30.1-59.4$ \\
\hline
\end{tabular}

** Interaction includes the finish speed.

( ) Variable not significant at the $90 \%$ confidence level.

Generally, when there is a clear, large effect of any individual variable on tensile properties, that variable is the furnace temperature for samples at stand 4 and the finish mill speed for samples at stand 16 .

Stress-Rupture Tests

The data for all the tests are listed in Table V. Here it is clcar that the temperature of the furnace is the most important variable at stand 4 , the picture becomes unclear at stand 8 , and at

Table V. Stress-Rupture Test Results

\begin{tabular}{|c|c|c|c|c|c|c|}
\hline \multirow{2}{*}{$\begin{array}{c}\text { Stand } \\
\text { No. }\end{array}$} & \multirow[t]{2}{*}{ Property } & \multirow{2}{*}{$\begin{array}{c}\text { Most } \\
\text { Significant } \\
\text { Variable }\end{array}$} & \multicolumn{2}{|c|}{ Low Setting } & \multicolumn{2}{|c|}{ High Setting } \\
\hline & & & Avg. & Range & Avg. & Range \\
\hline \multirow[t]{2}{*}{4} & Life (hrs) & Fce. Temp. & 105.5 & $87.5-143$ & 35.2 & $0.4-101$ \\
\hline & Elongation $(\%)$ & Fce. Temp. & 13.2 & $9-18$ & 3.4 & $0-12$ \\
\hline \multirow[t]{2}{*}{8} & Life (hrs) & (Fce. Temp.) & 61.2 & $48.0-84.4$ & 81.3 & $60.1-110$ \\
\hline & Elongation $(\%)$ & (Soaktime) & 16.6 & $9-28$ & 20.8 & $10-32$ \\
\hline \multirow[t]{2}{*}{12} & Life (hrs) & Finish Speed & 114.2 & $88.5-142.7$ & 58.3 & $0.4-158$ \\
\hline & Elongation $(\%)$ & Finish Speed & 13.8 & $7.5-26$ & 5.0 & $0-16$ \\
\hline \multirow[t]{2}{*}{16} & Life (hrs) & Finish Speed & 133.5 & $98.3-171$ & 16.1 & $0.5-117$ \\
\hline & Elongation $(\%)$ & Finish Speed & 17.7 & $10-32$ & 1.1 & $0-10$ \\
\hline
\end{tabular}

stands 12 and 16 the most important variable is the finish speed. Because of the number of notch failures, quite a few of the stress-rupture tests failed AMS 5662. Tables VI and VII illustrate the effect of furnace temperature and finish speed, respectively, on the occurrence of notch failures. 
Table VI. Percent of the Stress-Rupture Tests with Notch Failures

(Stands 4 and 8)

\begin{tabular}{|c|c|c|}
\hline \multirow{2}{*}{$\begin{array}{c}\text { Mill Stand } \\
\text { Number }\end{array}$} & \multicolumn{2}{|c|}{ Box Furnace Temperature } \\
\cline { 2 - 3 } & $\left.\mathbf{9 9 6}^{\circ} \mathbf{C ~ ( 1 8 2 5}{ }^{\circ} \mathbf{F}\right)$ & $\left.\mathbf{1 1 0 7}^{\circ} \mathbf{C ~ ( 2 0 2 5}{ }^{\circ} \mathbf{F}\right)$ \\
\hline 4 & 0 & 56 \\
\hline 8 & 0 & 0 \\
\hline
\end{tabular}

Table VII. Percent of the Stress-Rupture Tests with Notch Failures (Stands 8 through 16)

\begin{tabular}{|c|c|c|}
\hline \multirow[b]{2}{*}{$\begin{array}{l}\text { Mill Stand } \\
\text { Number }\end{array}$} & \multicolumn{2}{|c|}{ Intermediate/Finish Mill Speed } \\
\hline & $\begin{array}{c}213 \mathrm{~m} / \mathrm{min} \\
(700 \mathrm{ft} / \mathrm{min})\end{array}$ & $\begin{array}{c}305 \mathrm{~m} / \mathrm{min} \\
(1000 \mathrm{ft} / \mathrm{min})\end{array}$ \\
\hline 8 & 0 & 0 \\
\hline 12 & 0 & 56 \\
\hline 16 & 0 & 88 \\
\hline
\end{tabular}

At stand 4, Table VI shows all notch failures occur when the higher furnace temperature is used. When the material arrives at stand 8, the tendency for notch failures disappears. Continuing through stand 12 , Table VII indicates notch failures reappear only when the higher mill speed is used. By the time the material exits stand 16, nearly all the material rolled with the higher mill speed has notch failures. However, no notch failures occur for the slower mill speed. The balance of this paper will address the pronounced effects of furnace temperature and mill speed on stress-rupture performance.

\section{Temperatures}

The consequences of the high temperatures produced by the initial $1107^{\circ} \mathrm{C}\left(2025^{\circ} \mathrm{F}\right)$ billet soak temperature and the higher speed for the intermediate/finish mill can be demonstrated by Figure 2. Here the stress-rupture elongation for all 128 tests ( 32 billets rolled $x 4$ test locations per billet) are plotted against average surface bar temperature after the final rolling experienced by the samples. The temperatures paired with test samples cut after stands 4 and 16 were

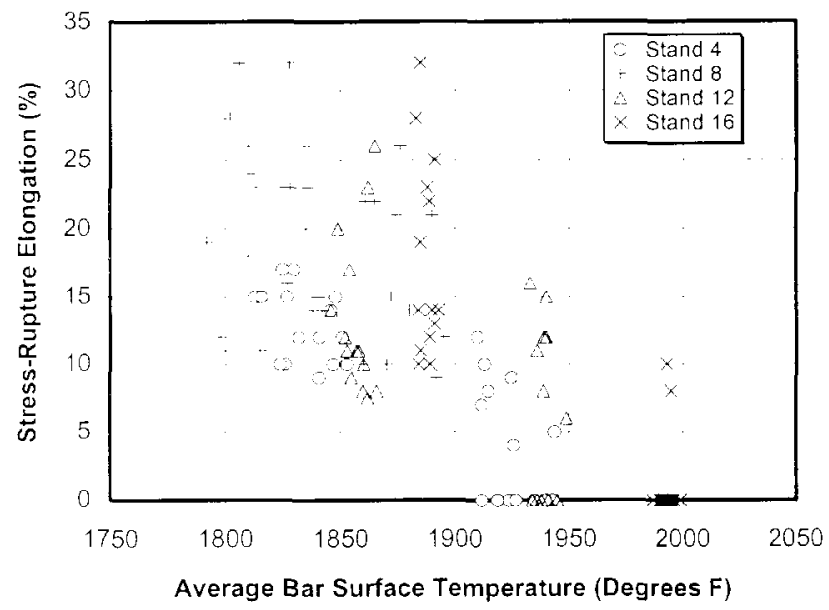

Figure 2. Effect of surface temperature for last rolling on stress-rupture elongation. measured by pyrometer shortly after the material exited these stands. For stand 12 samples, the temperatures used were those recorded as the material entered stand 13. The temperatures used for stand 8 samples are the averages of measurements taken at the entrance of stand 5 and at the entrance of stand 11 , and are thus only approximations. Even with these limitations, it is apparent that rolling above about $1043^{\circ} \mathrm{C}\left(1910^{\circ} \mathrm{F}\right)$ surface temperature, regardless of the variable that causes it, can lead to problems with stress-rupture ductility. 


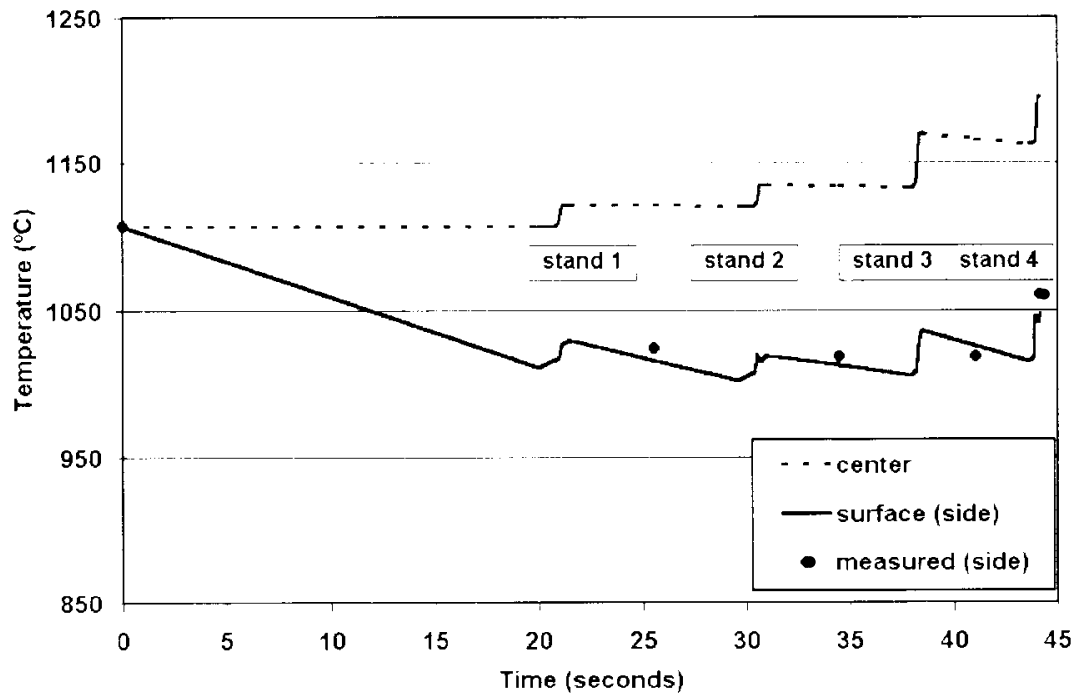

Figure 3 shows there is very close agreement between the measured surface temperatures and those predicted by the finite element model. In addition, the model predicts that with a furnace temperature of $1107^{\circ} \mathrm{C}$ $\left(2025^{\circ} \mathrm{F}\right)$, the temperature in the center of the bar exiting stand 4 has risen to $1204^{\circ} \mathrm{C}\left(2199^{\circ} \mathrm{F}\right)$. This is a condition associated with stress-rupture failures.

Figure 3. Temperature history of alloy 718 bar rolled in stands 1 -t of Allvac's continuous rolling mill.

\section{Cross Sections}

The model predicts billet shape following each stand. Figure 4 compares actual billet shapes with those predicted by the finite element model for stands 1 and 4 . The deviation from the measured dimensions for each stand is no more than $1 \%$, and typically is less than $0.5 \%$.
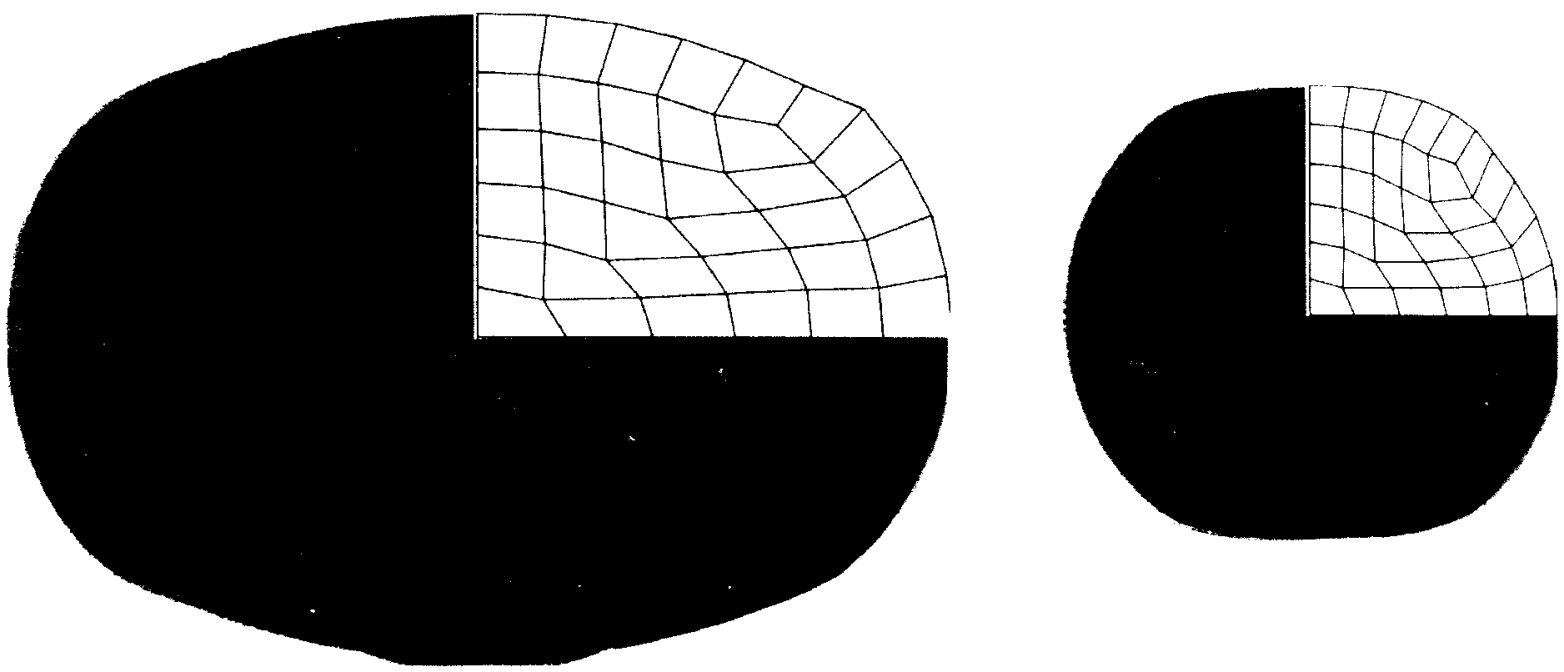

Figure t. Predicted and measured exit shapes for rolling alloy 718 billet at stands I (lefi) and $f$ (right) of Allvac's continuous rolling mill.

\section{Metallography}

Comparison grain size ratings for all 32 runs at 4 sampling locations each revealed that hotter surface temperatures immediately before sampling generally correlate with coarser grain sizes, lower strengths, and the tendency to produce stress-rupture notch failures. Conversely, colder surface temperatures correlate with finer grain sizes, higher strengths, and adequate stressrupture ductility. 
Figures 5 and 6 indicate there are general relationships between grain size and stress-rupture ductility and between delta phase and stress-rupture ductility, respectively, for the 22 stressrupture specimens on which intercept grain sizes and delta have both been measured.

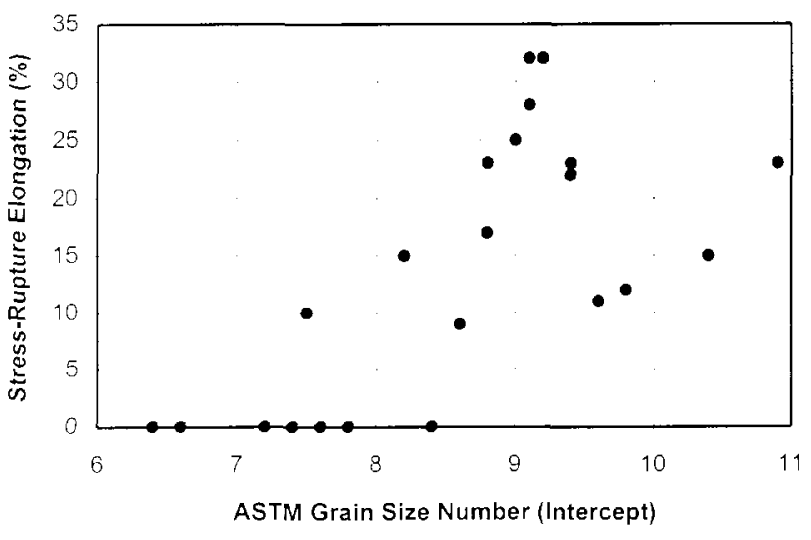

Figure 5. Correlation between ASTM grain size and stress-rupture ductility.

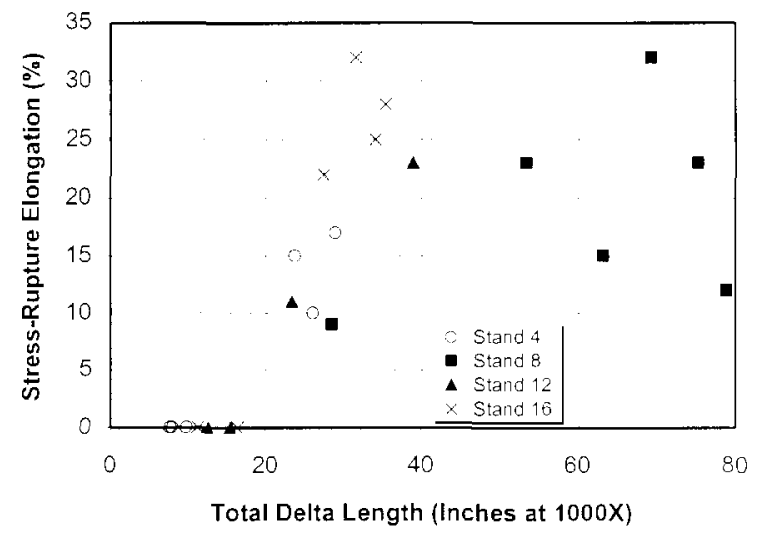

Figure 6. Correlation between amount of delta phase and stress-rupture ductility.

Goncrally, the finer the grain size, the higher the stress-rupture ductility. Grain sizes coarser than about ASTM 8.5 are present whenever stress-rupture notch failures are encountered in this study. In addition, Figure 6 shows that total lengths of delta phase less than about $50 \mathrm{~cm}(20 \mathrm{in})$ average per $1000 \mathrm{X}$ photo are measured for all the samples with notch failures. These samples all had grain sizes between ASTM 6.4 and 8.4. When the total delta is between about 50 and $100 \mathrm{~cm}$ (20 and $40 \mathrm{in}$ ), increasing amounts of delta result in improved stress-rupture ductility. This second group of samples all had somewhat finer grain sizes ranging from ASTM 7.5 to 9.6. Above about $130 \mathrm{~cm}$ (50 in), the stress-rupture ductility appears to decrease with increasing amounts of delta; all samples with this large amount of delta were taken after stand 8 where surface temperatures were relatively low. This third group of samples had grain sizes from ASTM 9.2 to 10.9 .

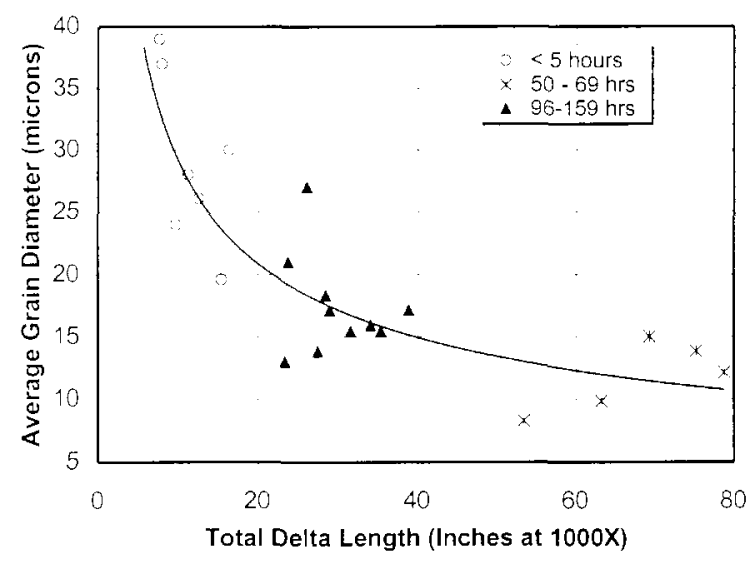

Figure 7 illustrates the interrelationship between stress-rupture life, total length of delta measured on $1000 \mathrm{X}$ SEM photos, and the average intercept grain diameter converted to microns using Table 2 in ASTM specification E 112 (4). The data points fall into three clusters defined by their stress-rupture life. All the specimens with notch failures had lives less than 5 hours and little delta. The specimens with intermediate amounts of delta had the longest lives, 96 to 159 hours. Finally, the specimens with the most delta all came from stand 8 and had intermediate lives of 50-69 hours.

Figure 7. Stress-rupture life influenced by grain size and delta precipitation.

Figures 8 and 9 demonstrate the variation in microstructure observed in this study as seen in SEM photos.

The results of this study agree with findings in the literature. Coarse grains $(6,8,13)$ and a small amount of delta phase in grain boundaries $(6,7,9,13)$ have previously been linked with low stress-rupture ductility and/or the tendency for notch failures. Some investigators have also reported that there is an optimal amount of delta phase in the grain boundaries for maximum 
stress-rupture ductility, with greater or lesser amounts leading to brittleness $(8,9,11)$. In addition, fine platelets and especially globular particles of delta in grain boundaries are frequently beneficial, while long platelets tend to be detrimental $(6,9,10,12,14,15)$. The proper distribution of fine delta phase particles along grain boundaries can redistribute stresses, reducing grain boundary sliding and/or lowering the tendency to produce and grow wedge cracks at triple points $(7,9,10,11,13)$. However, numerous, large, acicular platelets of delta phase can provide an easy path for stress-rupture crack propagation (12).

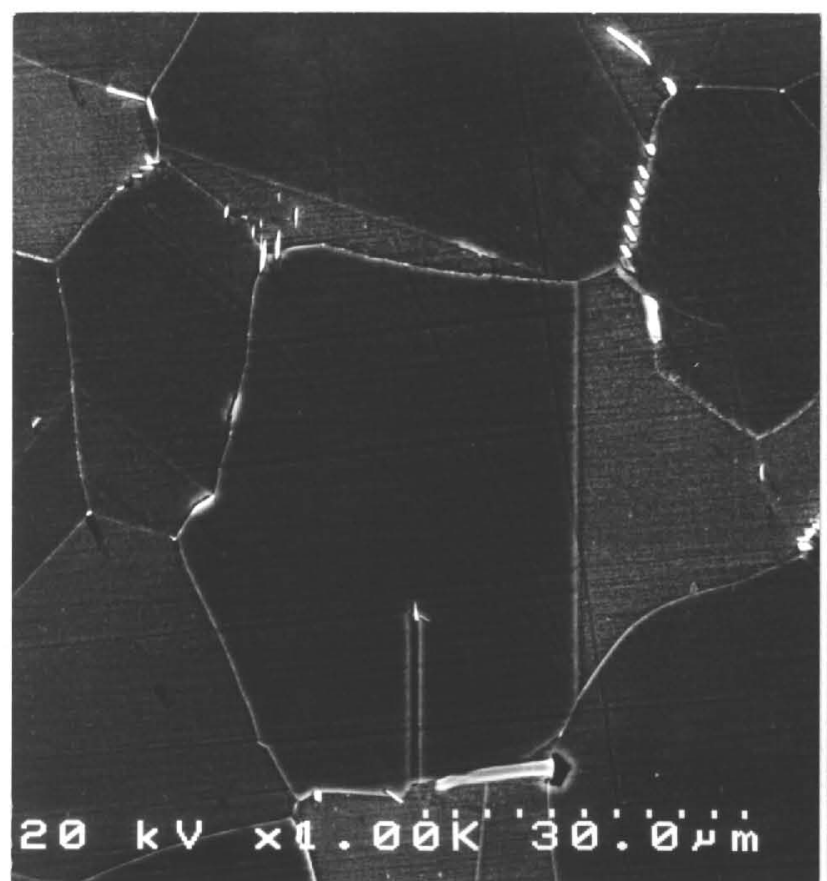

Figure 8. After stand 4. Intercept grain size $=$ ASTM 7.8. Length of delta $<7$ in $(18 \mathrm{~cm})$. Stress-rupture elongation $=0 \%$ Photo is cropped $28 \%$ to fit.

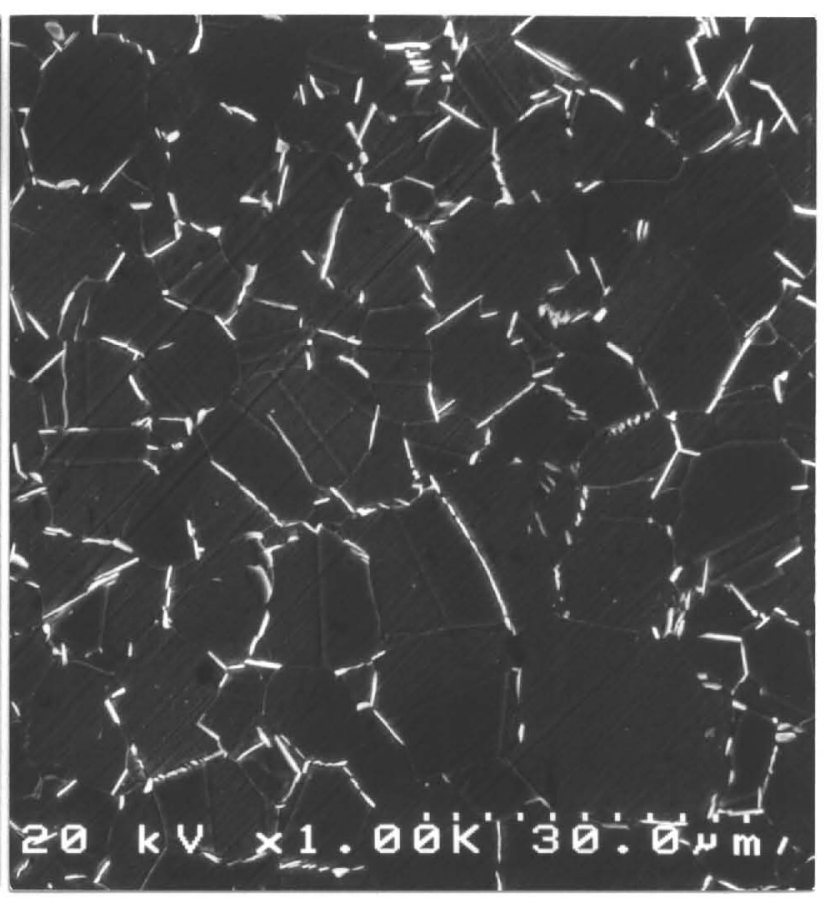

Figure 9. After stand 8.

Intercept grain size $=$ ASTM 10.9.

Length of delta $=46$ in $(117 \mathrm{~cm})$.

Stress-rupture elongation $=23 \%$.

Photo is cropped $28 \%$ to fit.

\section{Conclusions}

1. Billet soak temperature and mill speed are the main factors influencing mechanical properties and microstructure; higher soak temperatures and faster mill speeds produce higher temperatures in the material being rolled.

2. The higher material temperatures result in coarser grain sizes, less delta phase precipitation in the heat-treated bar, lower strength, and lower stress-rupture ductility.

3. When the final rolling prior to cutting samples was performed with a material surface temperature greater than about $1043^{\circ} \mathrm{C}\left(1910^{\circ} \mathrm{F}\right)$, there was a high probability of notch failures in stress-rupture tests. No failures were observed when rolling occurred below this temperature, regardless of the location along the mill where the samples were taken.

4. Stress-rupture notch failures occurred only in samples with grain sizes coarser than about ASTM 8.5 and with less than about $50 \mathrm{~cm}$ (20 in) of delta phase measured on SEM photos at 1000X. Not all samples with grain sizes coarser than ASTM 8.5 experienced notch failures, but all those with less than $50 \mathrm{~cm}$ (20 in) of delta failed in the notch.

5. A finite element model has been developed and is being used to analyze data from the rolling mill and to optimize rolling parameters for 718 and other alloys. 


\section{References}

1. H.B. Bomberger, "State-of-the-Art Bar and Rod Rolling Mill for Titanium and Other Special Mill Products," Light Metal Age, December, 1991, 21-23.

2. T.P. McAloon, "Innovative Bar and Rod Rolling Mill Commissioned by Teledyne Allvac," Iron \& Steelmaker, January, 1992, 36-37.

3. E.G. Thompson, R.S. Minisandram, R. Forbes-Jones and R. Stedje-Larsen, "Numerical Simulation of a Multi-Stand Rolling Mill," (Paper to be presented at The $7^{\text {th }}$ International Conference on Numerical Methods, NUMIFORM 2001, Toyohashi, Japan, 18-21 June $2001)$.

4. ASTM Specification E 112-96, American Society for Testing and Materials, 100 Barr Harbor Drive, West Conshohocken, Pa 19428-2959.

5. Aerospace Materials Specification AMS 5662, Society of Automotive Engineers, 400) Commonwealth Drive, Warrendale, Pa 15096-0001.

6. J.P. Stroup and R.A. Heacox, "Effect of Grain Size Variations on the Long-Time Stability of Alloy 718" (Paper presented at the International Symposium on Structural Stability in Superalloys, Champion, Pa., September 4-6, 1968), 544-577. Also Journal of Metals, November, 1969, 46-54.

7. S. Srinivas, et al., "An Investigation on Notch Embrittlement of a Ni-Base Superalloy," Scripta Metallurgica et Materialia, 32 (8) (1995), 1145-1148.

8. D.R. Muzyka and G.N. Maniar, "Effects of Solution Treating Temperature and Microstructure on the Properties of Hot Rolled 718 Alloy," Metals Engineering Quarterly, 9 (4) 1969, 23-37.

9. J.F. Muller and M.J. Donachie, Jr.,"The Effects of Solution and Intermediate Heat Treatments on the Notch-Rupture Behavior of Inconel 718," Metallurgical Transactions A. 6A, (December) (1975), 2221-2227.

10. S. Li et al., "The Effect of $\delta$-Phase on Crack Propagation under Creep and Fatigue Conditions in Alloy 718," (Paper presented at Superalloys 718, 625, 706, and Various Derivatives, Pittsburgh, Pa, 26-29 June 1994), 545-555.

11. W. Chen and M.C. Chaturvedi, "The Influence of Grain Boundary Precipitates on Creep Fracture of Inconel 718," (Paper presented at Superalloys 718, 625, 706, and Various Derivatives, Pittsburgh, Pa, 26-29 June 1994), 567-577.

12. S. Srinivas, et al., "Stress Rupture Property -- Microstructure Correlation in Hot-Rolled Superalloy 718," Materials Characterization, 35 (1995) 93-98.

13. W. Chen and M.C. Chaturvedi, "Dependence of Creep Fracture of Inconel 718 on Grain Boundary Precipitates," Acta Materialia, 45 (7) (1997) 2735-2746.

14. B. Pieraggi and J.F. Uginet, "Fatigue and Creep Properties in Relation with Alloy 718 Microstructure," (Paper presented at Superalloys 718, 625, 706, and Various Derivatives, Pittsburgh, Pa, 26-29 June 1994), 535-544.

15. N.A. Wilkinson, "Forging of 718 - The Importance of T.M.P.," (Paper presented at Superalloy 718--Metallurgy and Applications, Pittsburgh, Pa., 12-14 June 1989), 119-133. 